\title{
Türkiye'de Zeytinyağında Kalite ve Markalaşmanın İncelenmesi
}

\section{Dilek ÖZDOĞAN ${ }^{1}$ (D), Renan TUNALIOĞLU ${ }^{* 1}$ \\ ${ }^{1}$ Aydın Adnan Menderes Üniversitesi Ziraat Fakültesi Tarım Ekonomisi Bölümü}

Öz: Bu araştırmada, dünyada önemli zeytin ve zeytinyağı üreticisi ülkeler arasında yer alan Türkiye'nin kaliteli ve markalı zeytinyağı üretimindeki durumu incelenmiştir. Dünyada olduğu gibi Türkiye'de de kaliteli zeytinyağı üretiminde; zeytinin çeşidi, yetiştiği yöredeki iklim ve toprak, üretimde uygulanan kültürel işlemler, emek-yoğun hasat ve zeytini yağa işleme ve sonrasındaki işletme şartlarının en önemli kriterler olduğu tespit edilmiştir. Bu kriterlerin sağlanması koşuluyla üretilen zeytinyağında, kalite ve markalaşmanın tescillenmesinde ise ulusal ve uluslararası yarışmaların önemi büyüktür. Nitekim bu araştırmada, Türkiye'nin kaliteli ve markalı üretimine önem veren, özel ve özenli üretim yapan, kendilerini butik üretici olarak ifade eden ulusal ve uluslararası zeytinyağı kalite yarışmalarına katııı ödül alan, kalite ve markalarını tescillendiren 21 adet firma sahibi ile görüşülmüştür. Bu 21 adet firmanın 5 adedi uluslararası, 8 adedi ulusal ve 8 adedi hem ulusal hem de uluslararası yarışmalardan ödül almıştır. Araştırmada nicel ve nitel yöntem kullanılmış, yarı yapılandırılmış derinlemesine mülakat sonucu elde edilen veriler, nitel yöntem gereği kodlanarak sınıflandırılmışır. Ayrıca söz konusu zeytinyağı firmalarııı sosyo- demografik özellikleri, işletme kapasiteleri, marka tanııılıkları ve yarışmalardan aldıkları ödül durumlarını içeren veriler, nicel yöntem gereği gruplar arasında farklılıkları, Kruskal Wallis Testi ile incelenmiştir. Diğer yandan ulusal ve uluslararası yarışmaların kalite ve markalaşma sürecini olumlu etkilenmekte olduğu, firmaların ulusal ve uluslararası rekabet güçlerini test edildiğini ve uluslararası platformda tanınırlıklarının sağlandığı anlaşılmıştır.

Anahtar Kelimeler: zeytinyağı, kalite, markalaşma, ödül, yarışmalar, butik üretim

\section{Examination of Quality and Branding on Olive Oil in Turkey}

\begin{abstract}
In this research, important olive and olive oil producers in the world among countries of Turkey, was examined the situation in quality and branded olive oil production. Turkey as well as in the world in the quality of olive oil production; It is determined that the most important criteria are the types of olives, climate and soil in the region, cultural practices applied in production, labor-intensive harvesting and processing of olives in oil and the conditions after them. National and international competitions are of great importance in the production of olive oil produced on the condition that these criteria are met and in the registration of quality and branding. Interviewed in fact, this research, Turkey's high quality and branded with an emphasis on production, private and attentive engaged in manufacturing, he won prizes participating boutique producers as representing national and international olive oil quality competition the quality and the owner of 21 companies brands registrated which 5 were international, 8 national and international competitions. Quantitative and qualitative methods were used in the study and the data obtained as a result of semi-structured in-depth interviews were classified according to the qualitative method. In addition, the data including the socio-demographic characteristics, operating capacities, brand recognition and award status of the olive oil companies were analyzed by Kruskal Wallis Test. On the other hand, it is understood that the quality and branding process is effected from national and international competitions, thus competitive capacities of the firms are tested and eventually these activities would enable the firms recognized at the international level.
\end{abstract}

Keywords: olive oil, quality, branding, awards, competitions, boutique production

\section{GiRiş}

İnsanların sağlıklı ve uzun yaşam idealleri, bilinçli tüketicileri kaliteli ve güvenli gıda tüketimine yönlendirmektedir (Tunalıoğlu, 2010). Kalite, bir firmanın ürettiği ürünleri aynı amaç ile başka firmalarca üretilen ürünlerden ayıran özelliklerin toplamı ve gıda ürünlerinde tüketiciler tarafından benimsenen özelliklerin tümüdür (Güney, 2015). Bir başka ifade ile tüketicinin ihtiyacını karşılayan bir ürün, objektif (ürünün enerji, vitamin, mineral, toksin madde içeriği ve tazeliği) ve subjektif (ürünün rengi, şekli, tat ve kokusu vb.) değerlere sahipse kaliteli olarak kabul edilmektedir (Dölekoğlu, 2003). Kalite, hem üretici hem satıcı açısından ve tüketiciye verilen değer bakımından marka kavramı ile belgelenmektedir ve marka işletmeler tarafından rekabette stratejik bir unsurdur (Ijpek, 2010). Bu nedenle kalite odaklı markalaşma sürecinde marka denilince akla ilk gelen kavram çoğu zaman kalite kavramıdır (Parmak, 2011). Diğer yandan kaliteli ürün tercihinde bulunan tüketiciyi gıda güvenlik yönetim sistemleri korumaktadır. Gıda güvenliği, doğrudan gıdalardan kaynaklanan her türlü sağlık problemlerine karşı olan önlemlerin tümünü kapsamaktadır. Bu nedenle de gıda ürününün güvenli olması, bilinçli tüketicinin mutlak talebi iken üreticinin ise sorumluluğunda ve bu bağlamda birbirini takip eden bir oluşumda yer almaktadır (Kızılaslan ve Yalçın, 2012).

Markalı ürün, kalitenin güvencesidir ve risk algısını

Sorumlu Yazar: renan.tunalioglu@gmail.com Bu çalışma yüksek lisans tez ürünüdür.

Geliş Tarihi: 3 Ocak 2019

Kabul Tarihi: 26 Haziran 2019 
azaltmaktadır. Çünkü tüketiciler markanın kimliği sayesinde belirli bir ürünün temsil edildiğine güvenmekte ve olası bir aksi durumda muhatabın kim olduğunu bilmektedirler (Erdil ve Uzun, 2010). Marka farkındalığı oluşturmak, olumlu bir itibar sağlamayı beraberinde getirmektedir. Üretici firmaların yeni ürünlerini veya var olan ürünlerini tüketici ile buluşturma arzusu her dönem önemsenen bir konudur. Marka bağııı̆ı konusunda firmalar çeşitli kampanyalar düzenleyerek tüketici ile iletişime geçmeyi hedeflemekte (Demir, 2015), bu sebeple de ambalajlı ve markalı ürünlerin önemi her geçen zaman daha da artmaktadır (İpek, 2010).

Zeytin ve zeytinyağı ise Akdeniz beslenme piramidinin ilk katmanlarında yer alan, sağlıklı ve uzun yaşama isteği olan insanoğlu için (Tunalıoğlu, 2010), kendine özgü lezzet, renk, koku ve aromasıyla önemli bir gıda maddesidir (Özata ve Cömert, 2016).

Zeytinyağı, taze ve olgun zeytin meyvesinden presleme, santrifüjleme ve süzme ile mekanik olarak elde edilen, oda sıcaklığında $20-25{ }^{\circ} \mathrm{C}$ sıvı olarak korunan ve gıda olarak kullanılan bitkisel bir yağdır. Bu özellik, zeytinyağına tüm bitkisel yağlar arasında ham olarak yani rafinasyona tabi tutulmaksızın yenilebilen tek yağ özelliğini kazandırmaktadır. Zeytinyağı, kalori değeri yüksek, esansiyel yağ asitlerinin kaynağı ve yağda çözünen $A, D, E, K$ vitaminlerinin deposu olan kendine has tadı ve aroması ile diğer bitkisel yağlara göre tercih edilen, sağlık açısından son derece önemli olan ve natürel olarak tüketilebilen bitkisel bir yağ çeşididir (Keçeli, 2008). Sızma zeytinyağının kaliteli olarak elde edilmesini, zeytinin çeşidi, iklim ve toprağa bağlı olarak ve üretimin koşulları yanında depolama ve dağıtma süreçleri etkilemektedir (Peri, 2014). Diğer bir ifade ile zeytinyağında kaliteyi, zeytin çeşidi, yöre ikliminden aldığı rüzgâr, toprağın verimi, zeytinin hasat zamanı, şekli ve zeytini yağa işleme süreci, işlemede kullanılan makine ve ekipmanların tipi, zeytinyağının depolanması ve ambalajlanması gibi değişkenlerin bileşimi etkilemektedir (Özdoğan ve Tunalıoğlu, 2017). Zeytinyağında kalite, kimyasal ve duyusal analizlerle tespit edilmektedir (Baş ve Yaman, 2015). Zeytinyağının, elde edilmesinden tüketiciye ulaşıncaya kadar kalitesinde meydana gelebilecek bozulmaların önlenmesi için uygun şartlarda depolanması ve antioksidan özelliklerinin korunması için mevcut yağ asidi kompozisyonun dolayısıyla kalitesinin korunması, diğer bitkisel yağlara göre daha uzundur ama bu süre sınırsız değildir (Keçeli, 2008).

Bu araştırmada, Türkiye'de zeytin ve zeytinyağı sektöründe faaliyet gösteren özel ve özenli üretim yapan işletmelerin, zeytinyağında kalite ve markalaşma stratejileri incelenmiştir. Bu işletmelerin kalitelerini belgeledikleri, uluslararası ve ulusal yarışmalara katılımları, bu yarışmaların zeytinyağı üreticilerine katkıları, kalite ve markalaşma çalışmaları ortaya konulmuştur.

\section{MATERYAL VE YÖNTEM \\ Materyal}

Araştırmanın birincil verileri, Türkiye zeytin ve zeytinyağı üretiminin yüzde yetmiş beşini sağlayan, Ege, Marmara ve Akdeniz Bölgelerindeki önemli üretici illerde bulunan (Aydın, İzmir, Muğla, Balıkesir ve Mersin), kaliteli ve markalı üretim yapan, ulusal ve uluslararası zeytinyağı kalite yarışmalarından ödül kazanan, firma sahipleri/ firma yöneticileri ile yüz yüze yapılan görüşmelerden elde edilmiştir. Bu firmalar toplamda 21 adet olup, birinci grup (ulusal zeytinyağı yarışmalarından ödül almış) 8 adet, ikinci grup (uluslararası zeytinyağı yarışmalarından ödül almış) 5 adet üçüncü grup (hem uluslararası hem ulusal zeytinyağı yarışmalarından ödül almış) 8 adettir. Araştırmanın ikincil verilerini ise konu ile ilgili bilimsel çalışmalar (tez, rapor vb.) ile uluslararası ve ulusal yarışmalara katılma prosedürleri ve ilgili mevzuatlar oluşturmuştur. Bu projede firmalarla yapılan görüşmelerde alınan ses kayıtları, Aydın Adnan Menderes Üniversitesi Rektörlüğü Sosyal ve Beşeri Bilimler Araştırmaları Etik Kurulu'nun 01.07.2016 tarih ve 903.07.01-003 sayılı kararı kapsamında gerçekleştirilmiştir.

\section{Yöntem}

Araştırmada, nitel ve nicel araştırma yöntemlerinden faydalanılmıştır. Nitel araştırma yöntemi, çalışılan konuyu derinlemesine ve tüm olası ayrıntıları ile incelemeyi amaç edinen önemli kavramların belirlenmesi ve detaylandırımasını önemseyen tekrarlamalı sürecin önemli bir parçasıdır ve konuyu derinlemesine ve tüm olası ayrıntıları ile incelemeyi amaç edinmektedir (Schutt, 2011). Nicel araştırma yöntemi ise ankete dayalı olarak elde edilen veriler ve çeşitli istatistiksel yöntemlerle analiz edilmektedir (Kalaycı, 2016).

Araştırmada doğru bilgi kaynağına ulaşabilmek için öncelikli olarak uluslararası yarışmalar tespit edilmiş, ülkemizde bu yarışmalardan ödül alan ve bu ödüllerde süreklilik gösteren, ulusal ve uluslararası rekabette yer alan, yarışmalarla kalite ve markalarını kanıtlayan firma sahipleri/ yöneticileri ile ortalama 20-25 dakika süren yarı- yapılandırılmış mülakatlar yapılarak araştırma etiği gereği firma bilgileri gizli tutulmuştur. Çözümlenen mülakatlar birincil, ikincil ve üçüncül aşamalı kodlamalarla sınıflandırılmıştır. Birinci dereceden kodlama anlamına gelen "Açık Kodlama" da, oluşan analitik temalara göre veri örnekleri alınmış, ikincil dereceden kodlamada, kodlama kategorileri arasındaki bağlantılar bulunmuş (Kalof ve ark., 2008), üçüncül dereceden/seçici kodlamada ise temel kategoriler ifade edilmiştir. Kodlamalar sayesinde, incelenen sorunlar ve açıklamaların aralarındaki ilişkiler düzenlenmiştir. Gizlilik 
çerçevesinde yapılan görüşmelerde uluslararası yarışmalardan ödül alan firmalar $\left(F_{1-l}, F_{2-l}\right.$ vb.). Ulusal yarışmalardan ödül alan firmalar $\left(F_{1}-N, F_{2}-N\right.$ vb.), hem uluslararası hem ulusal yarışmalardan ödül alan firmalar ise ( $\mathrm{F}_{1} \mathrm{I} \mathrm{I} / \mathrm{N}, \mathrm{F}_{2} \mathrm{l} / \mathrm{N}$ vb.) ile kodlanmıştır.

Diğer yandan bu araştırma hipotezinde yarışmalara katılan zeytinyağı firmaları üç grup halinde incelenerek farklılıklar analiz edilmiştir. Bu üç grup; uluslararası, ulusal ve her iki yarışmadan da ödül almış firmalara dayalı olarak oluşturulmuştur.

Nitel metotla görüşme yapılan firmalara nicel yöntemle elde edilen veriler Excel programına aktarılarak SPSS 20.0 istatistiksel paket programında analiz için hazır hale getirilmiştir. Öncelikle üç grup esas alınarak, zeytinyağı firmaların sahipleri/ firmaların yöneticilerinin sosyo demografik özellikleri, zeytinyağı firmalarının işletme özellikleri, firmaların marka, ödül ve kalite durumları arasındaki farklılıklar incelenmiştir. Bu özelliklere ait Çizelge 1. Zeytinyağı firmaları firma yönetici/firma sahiplerin

$*, * *, * * *$ sırasıyla $\mathrm{p}<0,10, \mathrm{p}<0,05$ ve $\mathrm{p}<0,01$ istatiksel önem düzeyini ifade etmektedir.

Bu firma sahipleri/yöneticilerinden, birinci grup işletmeler (ulusal) ortalama olarak 37,13; ikinci grup işletmeler (uluslararası) 36,20; üçüncü grup işletmeler (hem ulusal hem uluslararası) 49,50 yaş ortalamasına sahip olup, üçüncü gruptaki işletmelerin yönetici/sahiplerinin yaş ortalamalarının diğer gruplara göre büyük olduğu tespit edilmiştir. İşletme grupları arasındaki farklılığın, yaş açısından istatistiki olarak önemli olduğu $(p<0,05)$ belirlenmiştir. Eğitim açısından ikinci grup işletme yöneticisi/sahiplerinin en yüksek eğitim düzeyine sahip oldukları, bunu birinci ve üçüncü grubun izlediği görülmektedir.

Firma sahip ve firma yöneticilerinin mesleki deneyimleri incelendiğinde, birinci grup işletmeler ortalama olarak 11,63 yıl; ikinci grup işletmeler 8,60 yıl; üçüncü grup işletmeler 14,25 yıl iş tecrübesine sahip fakat gruplar arasındaki farklılığın deneyim açısından istatistiki olarak önemli olmadığı belirlenmiştir. Diğer yandan firmaların
ÖZDOĞAN D, TUNALIOĞLU R verilerin ortalama, standart hata, minimum ve maksimum değerleri gibi tanımlayıcı istatistikleri ortaya konulmuştur. Daha sonraki, aşamada örneklem değeri 30'un altında olduğu için ve gruplar arasındaki karşılaştırma yapmayı sağlamak için Non-Parametrik test olan Kuruskal Wallis Testi uygulanmıştır (Kalaycı, 2016).

\section{BULGULAR VE TARTIŞMA}

Dünya zeytinyağı terminolojisinde butik üretim ya da butik işletmenin kesinleşmiş bir tanımı henüz mevcut değildir. Bu nedenle araştırmada, görüşme yapılan firmaların seçiminde, uluslararası ve ulusal yarışmalara özgü kalite kriterlerini esas alan özellikte üretim yapıyor olmaları ve bir kısmının da "Butik Zeytin ve Zeytinyağı Üreticileri Derneği" adı altındaki bir çatıda yer almış olmalarına dikkat edilmiştir.

$\mathrm{Bu}$ araştırmada, zeytinyağı firma yöneticilerinin/firma sahiplerinin sosyo demografik özellikleri Kruskal Wallis testiyle incelenmiştir. Firma sahiplerinin/yöneticilerinin yaş, cinsiyet, eğitim ve deneyimleri (Çizelge 1 )'de gösterilmiştir.

sosyo demografik özellikleri

\%52,4'ünün, günde 1-5 ton arasında zeytin işlediği üretimde miktara değil kaliteye önem verdikleri anlaşılmaktadır. Normal şartlarda zeytinyağı işletmeleri günde 50 ve 100 ton arasında zeytini yağa işlemektedir (Yıldırım ve Tunalıoğlu, 2016).

Dünyada olduğu gibi Türkiye'de de, zeytinyağı sektörünün dağınık olması nedeniyle firmalar kalite ve markaya aynı özeni göstermemektedir. Araştırmada görüşme yapılan özel üretim yapan zeytinyağına farklı katma değer yaratan, kalite ve markanın farklılığını fark eden firmalar, uluslararası ve ulusal yarışmalardan aldıkları ödüllerle kendilerini kanıtlamaktadırlar. Özel ve özenli üretim yapan zeytinyağı firmalarının kalite ve markaları ulusal ve uluslararası yarışmalardan aldıkları ödüllerle tescil ettirilmektedir (Çizelge 2). 
Çizelge 2. Uluslararası ve ulusal ve her iki yarışmaya katılan firmaların kodlamaları

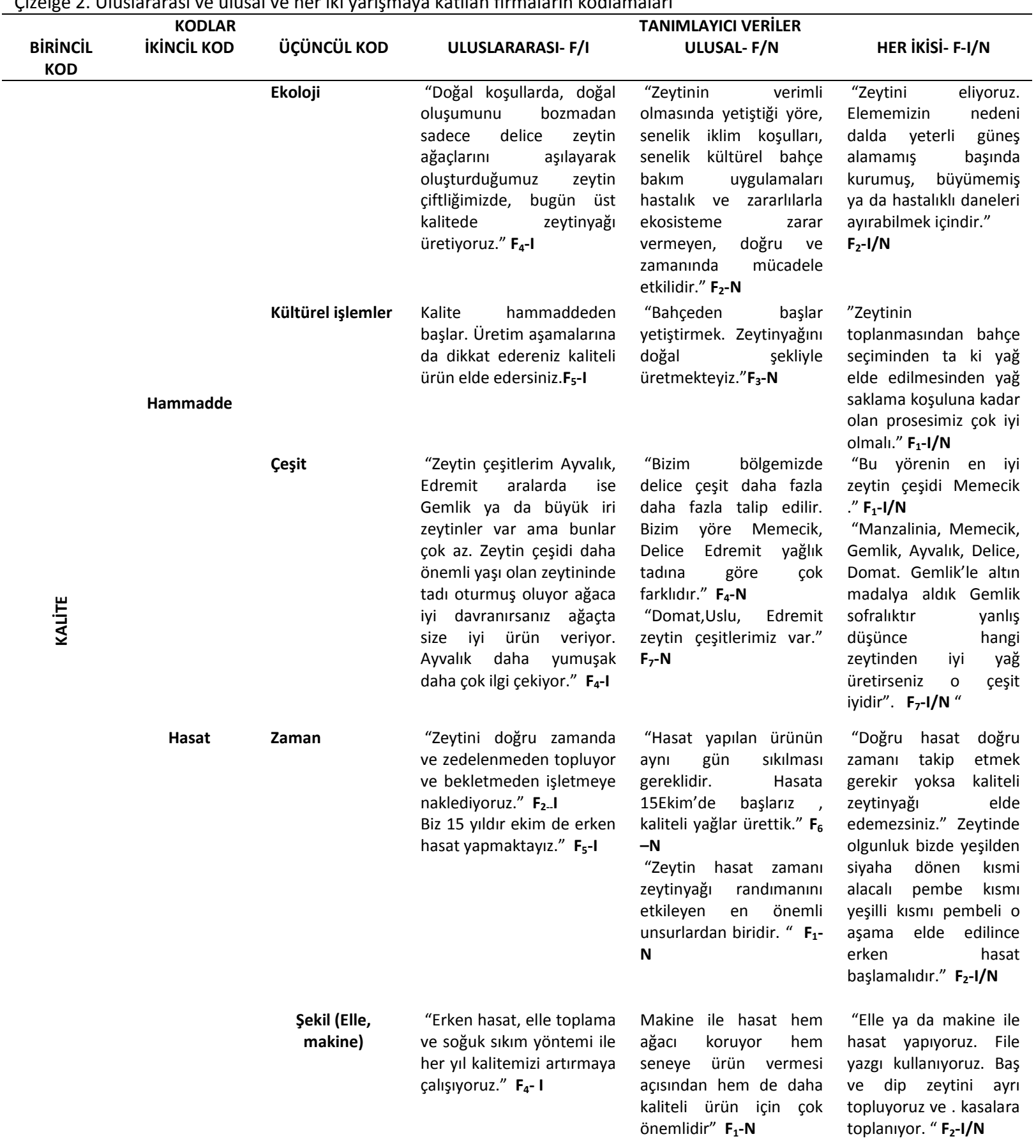


Çizelge 2. Uluslararası ve ulusal ve her iki yarışmaya katılan firmaların kodlamaları (devamı)

\begin{tabular}{|c|c|c|c|c|c|}
\hline & KODLAR & & & TANIMLAYICI VERILER & \\
\hline BIRINCIL KOD & IKINCIL KOD & $\begin{array}{l}\text { ÜÇÜNCÜL } \\
\text { KOD }\end{array}$ & ULUSLARARASI- F/I & ULUSAL- F/N & HER íkisi- F-I/N \\
\hline 崖 & $\begin{array}{c}\text { İşleme } \\
\text { Teknolojisi }\end{array}$ & $\begin{array}{l}\text { İki faz üç faz } \\
\text { (Kontinü } \\
\text { sistemler) }\end{array}$ & 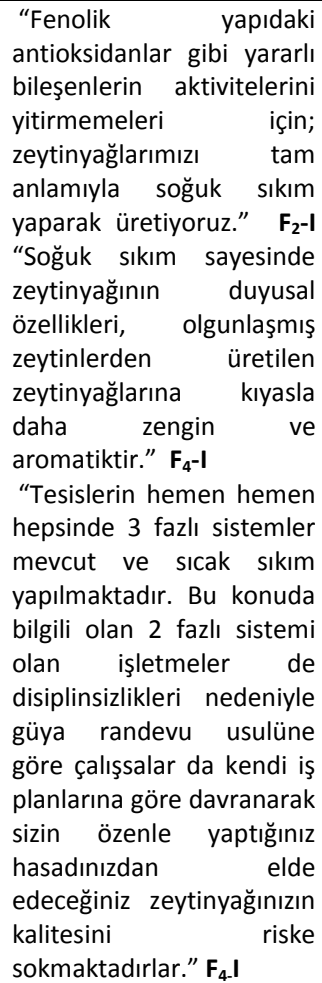 & $\begin{array}{lr} & \\
\text { “Sadece } & \text { kendi } \\
\text { zeytinlerimizi işlediğimiz } \\
\text { fabrikamızda kurulu olan } \\
\text { iki fazlı kontinü } & \text { sistemle } \\
\text { soğuk sıkım üretim } \\
\text { yapıyoruz." } \mathbf{F}_{2}-\mathbf{N}\end{array}$ & $\begin{array}{lr}\text { "Zeytin sıkım } & \text { hattında } \\
\text { toplanan } & \text { zeytinleri } \\
\text { fabrikaya } & \text { geldikten } \\
\text { sonra, } & \text { yıkama } \\
\text { temizleme bölümünde } \\
\text { hava püskürtmeli } \\
\text { basınçlı su ile güzelce } \\
\text { yıkanmalıdır." F4-I/N }\end{array}$ \\
\hline
\end{tabular}


Çizelge 2. Uluslararası ve ulusal ve her iki yarışmaya katılan firmaların kodlamaları (devamı)

\begin{tabular}{|c|c|c|c|c|c|}
\hline \multirow{2}{*}{ BiRiNCIL KOD } & \multirow{2}{*}{$\begin{array}{r}\text { KODLAR } \\
\text { IKINCIL KOD } \\
\end{array}$} & \multirow[b]{2}{*}{ ÜÇÜNCÜL KOD } & \multicolumn{3}{|c|}{ TANIMLAYICI VERILER } \\
\hline & & & ULUSLARARASI- F/I & ULUSAL- F/N & HER íisi- F-I/N \\
\hline \multirow{5}{*}{ 屴 } & \multirow{5}{*}{$\begin{array}{l}\text { Kimyasal } \\
\text { ve } \\
\text { Duyusal } \\
\text { Analiz }\end{array}$} & Peroksit & $\begin{array}{l}\text { “Peroksit yağın raf ömrünü } \\
\text { belirlerler peroksidi çok } \\
\text { yüksekse yağ yavaş yavaş } \\
\text { bozulmaya başlamıştır.20' } \\
\text { nin altında peroksit daha } \\
\text { iyidir. Zeytinyağı sünger } \\
\text { gibidir etraftaki kokuyu } \\
\text { hemen alır." } F_{5}-\mathbf{I}\end{array}$ & $\begin{array}{l}\text { "Zeytinyağı haricinde, yağlı } \\
\text { tohumlardan elde edilen } \\
\text { hemen hemen bütün diğer } \\
\text { yağlar hem fiziksel hem } \\
\text { kimyasal olarak koku } \\
\text { giderme ve tat giderme } \\
\text { işlemlerine tabi } \\
\text { tutulmaktadır. Yani rafine } \\
\text { edilmektedir." } \mathbf{F}_{6}-\mathbf{N}\end{array}$ & $\begin{array}{l}\text { "Kimyasal ve duyusal } \\
\text { analize bakan arkadaşların } \\
\text { hepsi tecrübelidir. } \\
\text { Zeytinyağını zeytinyağı } \\
\text { değil ilaç olarak da } \\
\text { görmekteyiz. İçindeki } \\
\text { antioksidanlar fenolik } \\
\text { bileşikler ne kadar değerli } \\
\text { olduğunu tıp bilim biliyor." } \\
\mathbf{F}_{2}-\mathbf{I} / \mathbf{N}\end{array}$ \\
\hline & & Serbest yağ asidi & $\begin{array}{l}\text { “Kendi içinde } \\
\text { zeytinyağlarımızın tatsal } \\
\text { aroma ayrımı asit } \\
\text { oranlarının zamanında } \\
\text { kimyasal ve duyusal } \\
\text { analizleri işleme sırasında } \\
\text { sürekli kontrol } \\
\text { edilmektedir." F2-ı }\end{array}$ & $\begin{array}{l}\text { “Bakım ve ilaç } \\
\text { yapmadığınızda asitler olur } \\
\text { natürel birinci yağ elde } \\
\text { edersiniz." F1/N }\end{array}$ & $\begin{array}{l}\text { "Kaliteli ve kalitesiz yağları } \\
\text { asit oranları kontrol } \\
\text { edilerek ayrılması } \\
\text { sağlanmaktadır.." } \text { F }_{2}-\mathbf{I} / \mathbf{N}\end{array}$ \\
\hline & & & $\begin{array}{l}\text { "Yağda acılık yakıcılık taze } \\
\text { badem kokusu taze sebze } \\
\text { kokusunu alacaksın. " F1-ı } \\
\text { Dengeli bir meyvemsiliği } \\
\text { yakıcılığı ve acılığı vardır." } \\
\text { F4-ı }\end{array}$ & $\begin{array}{l}\text { “Saklama koşulları çok } \\
\text { önemli 18- } 20 \text { derecede } \\
\text { krom tanklarda azot gazı } \\
\text { basılı bir şekilde ışıktan } \\
\text { ısıdan korunmalı zeytinyağı } \\
\text { çok hassas yanında }\end{array}$ & $\begin{array}{l}\text { "Hasattan yağ çıkana } \\
\text { kadar, işçilere sıvı sabun, } \\
\text { deodorant bile } \\
\text { kullandırmıyoruz. } \\
\text { Zeytinyağı kokuyu } \\
\text { sevmez.." F1-I/N }\end{array}$ \\
\hline & & $\begin{array}{l}\text { Meyvemsilik } \\
\text { (Koku) }\end{array}$ & & $\begin{array}{l}\text { bulundurduğunuz } \\
\text { ürünlerden bile koku } \\
\text { alabilir." F1/N } \\
\text { "Zeytinyağı ışık, hava ve } \\
\text { Isıdan olumsuz etkilenir. ." } \\
\text { F6-N }\end{array}$ & $\begin{array}{l}\text { "Sızma zeytinyağını } \\
\text { kokladığınızda biçilmiş } \\
\text { çimen, çağla, badem, yeşil } \\
\text { elma, yeşil domates, } \\
\text { enginar, olgunlaşmamış } \\
\text { muz kabuğu kokularını } \\
\text { andıran çekici geliyorsa, } \\
\text { mutlu hissettiriyor." F4-I/N }\end{array}$ \\
\hline & & $\begin{array}{c}\text { Acılık ve Yakıcılık } \\
\text { (Tad) }\end{array}$ & $\begin{array}{l}\text { "Duyusal analizi kendim } \\
\text { yapıyorum. Bizim halk Arap } \\
\text { zevkli tatlı yağ seviyor } \\
\text { şişenin içini görmek istiyor." } \\
\text { F1-ı "Aydın- Muğla'daki } \\
\text { memecik zeytini tadı daha } \\
\text { sert tüketici bilinçli olması } \\
\text { gerekir. Acılık yakıcılık hissi } \\
\text { çok önemli." F5-ı }\end{array}$ & $\begin{array}{l}\text { "Sağlığın iksiri sloganı ile } \\
\text { ürettiğimiz zeytinyağlarımız } \\
\text { taze kokusu ile dilinizde } \\
\text { hafif meyvemsi bir tat ile } \\
\text { başlayıp, hafif bademsi bir } \\
\text { aroma ile biten bir lezzet ile } \\
\text { kendini belli eder." F6-N }\end{array}$ & $\begin{array}{l}\text { "Sııma zeytinyağını bir } \\
\text { yudum ağzınıza alıp } \\
\text { damağınızın üzerinde } \\
\text { gezdirdiğinizde, yeşil zeytin, } \\
\text { acı badem veya elma } \\
\text { çekirdeği acılığı } \\
\text { hissediyorsanız ve } \\
\text { boğazınızda yakıcılık yemek } \\
\text { borunuza doğru inmiyorsa } \\
\text { bu sızma zeytinyağıdır." F4- } \\
\text { I/N }\end{array}$ \\
\hline
\end{tabular}


Çizelge 2. Uluslararası ve ulusal ve her iki yarışmaya katılan firmaların kodlamaları (devamı)

\begin{tabular}{|c|c|c|c|c|c|}
\hline \multirow{2}{*}{ BíRINCIL KOD } & \multirow{2}{*}{$\begin{array}{c}\text { KODLAR } \\
\text { iKINCIL KOD }\end{array}$} & \multirow[b]{2}{*}{ ÜÇÜNCÜL KOD } & \multicolumn{3}{|c|}{ TANIMLAYICI VERILER } \\
\hline & & & ULUSLARARASI- F/I & ULUSAL- F/N & HER ikisi- F-I/N \\
\hline 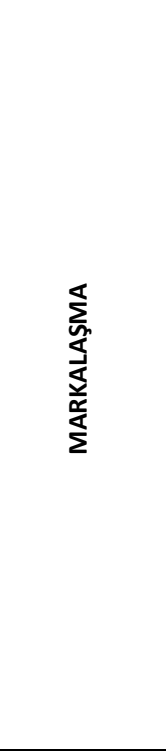 & Tescil & Güven & $\begin{array}{l}\text { “Marka özgün bir ürün veya } \\
\text { hizmetin kullanımının } \\
\text { alışkanlık haline gelmesidir. } \\
\text { Markalaşma ancak müşteri } \\
\text { markaya sahip olunca } \\
\text { gerçekleşir.” F2-ı } \\
\text { "Markalaştığınızda özel } \\
\text { olduğunuzu görüyorsunuz.” } \\
\text { F5-ı } \\
\text { “Benim markamın } \\
\text { zeytinyağlarını gördüğünde } \\
\text { insanlar bu kaliteli zeytinyağı } \\
\text { güvenli tüketebiliriz imajını } \\
\text { oluşturmak F3-ı } \\
\text { “Fiyatı etkiliyor bu şartlarda } \\
\text { bu zeytinyağı bu fiyata } \\
\text { sunuyoruz riviera yağ ile } \\
\text { natürel sızmayı bir tutmayın. } \\
\text { F2-I. } \\
\text { İyi fiyat iyi katma değer } \\
\text { kazandırıyor." F3-ı }\end{array}$ & $\begin{array}{l}\text { "Tüketici güvenini } \\
\text { kazandığınızı düşünüyorum. } \\
\text { Markalaştığınızda benim } \\
\text { yağım benim markamın } \\
\text { güvencesi diyebilirsiniz." F1- } \\
\text { N } \\
\text { "Üretimden paketlemeye } \\
\text { disiplin içinde olmalısınız } \\
\text { çünkü marka imajının iyi } \\
\text { olması için bunlar gerekli." } \\
\text { F3-N }\end{array}$ & $\begin{array}{l}\text { "Markayla beraber yağ ön } \\
\text { plana çıkıyor. "F2-I/N } \\
\text { "Markalaşma kaliteyi } \\
\text { kalite markayı getirir. " F3- } \\
\text { I/N } \\
\text { “Aileden gelen markaya } \\
\text { daha kaliteli devam } \\
\text { ettirmeyi çalışmak."F1-I/N } \\
\text { "Itibarınız artıyor. } \\
\text { Türkiye'yi temsil } \\
\text { ediyorsunuz." "F3-I/N }\end{array}$ \\
\hline \multirow{2}{*}{ 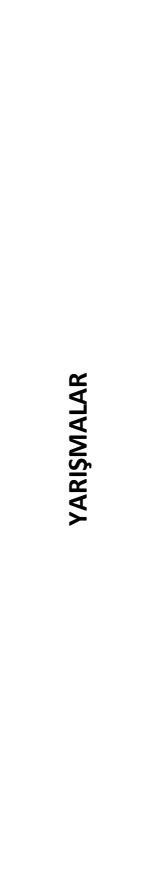 } & \multirow[t]{2}{*}{ Farkındalık } & Tanınırlık & $\begin{array}{l}\text { “Dünya standartlarının da } \\
\text { üstünde kendi içimizde } \\
\text { saklamak değil kalitemizi } \\
\text { dünyaya tanıtmak istedik } \\
\text { bunlar ABD, AB, Uzak } \\
\text { Doğuda buralardan ödüller } \\
\text { aldık." F2-I }\end{array}$ & $\begin{array}{l}\text { "Bu bölgenin yağları } \\
\text { kötüdür kokar olumsuz imaj } \\
\text { yaratmaya çalışan bölge ve } \\
\text { firmalar karşı çıkmak için } \\
\text { yarışmalara katılıyoruz, } \\
\text { hasat şenlikleri de kaliteli } \\
\text { yağ olduğunu bölgenin } \\
\text { gösterdi. Tanınılık ve } \\
\text { bilinilirliğini sağlamak için } \\
\text { uğraşıyoruz." F3-N } \\
\text { "Biz bu yarışmalara } \\
\text { katılarak bölge yağını } \\
\text { tanıttık, kanıtladık ve } \\
\text { tescilledik." F4-N }\end{array}$ & $\begin{array}{l}\text { "Yarışma bizim için } \\
\text { sadece tescilli olmaktır." } \\
\text { F2-I/N } \\
\text { “Amacım ürettiğim kaliteli } \\
\text { yağı sektör ve tüketicilerin } \\
\text { tanıması ve kalitemin } \\
\text { değerini görmek." F5-I/N }\end{array}$ \\
\hline & & Kanıtlamak & $\begin{array}{l}\text { "Yarışmada kalitenizi } \\
\text { ispatlıyorsunuz kuzey güney } \\
\text { yarım küreden yağlar } \\
\text { yarışıyor." F3-I “Kaliteli bir } \\
\text { zeytinyağı olduğunu } \\
\text { göstermekti." F1 -I “ } \\
\text { Yarışmalarla kalitenizi } \\
\text { tescillendiriyorsunuz. İşi bilen } \\
\text { kişiler tarafından } \\
\text { değerlendiriliyorsunuz." F5-I }\end{array}$ & $\begin{array}{l}\text { “Yarışmaya katılmakla } \\
\text { kaliteli yağ ürettiğinizi } \\
\text { ispatlamak." F1-N } \\
\text { "Türkiye'de bölge yağı ile } \\
\text { ilgili bir ön yargı vardı. bu } \\
\text { yarışmalarla iyi zeytinyağı } \\
\text { ürettiğimizi kanıtladık." F3-N } \\
\text { “Kalitemizi } \\
\text { tescillendirmektir." F7-N }\end{array}$ & $\begin{array}{l}\text { "Yurt içi ve yurt dışı } \\
\text { pazarlama esnasında } \\
\text { ödüller bizim için ispat } \\
\text { oluyor." F4-I/N } \\
\text { "Uluslararası düzeyde } \\
\text { neredeyiz bunu görmek } \\
\text { istiyoruz." F1-ı/N } \\
\text { "Emeğin karşılığını } \\
\text { görmek Türkiye'de ve } \\
\text { dünyada neredeyiz bunu } \\
\text { görmek." F7-I/N }\end{array}$ \\
\hline
\end{tabular}

Firmaların \%95,2'nin markası olduğu \%4,8'inin markasının olmadığı ve markası olanların ise \%95,2'nin katıldıkları yarışmalardan ödül aldıkları belirlenmiştir.

Zeytinyağı firmalarının marka ve ödül durumları Kruskal Wallis testi ile incelendiğinde ise marka tanınırlıkları, birinci grup firmalarda ortalama 0,88 , ikinci ve üçüncü grup firmalarda ise ortalama 1 hesaplanmıştır. Bu durumda ikinci ve üçüncü grup firmaların tanınırlıklarının istatistiki açıdan farklılık göstermediği belirlenmiştir.
Araştırma bulgularının nitel metot ile değerlendirilmesinde ise kodlamalar ile yapılmıştır. Bu kodlamalar; birincil, ikincil ve üçüncül kodlar olarak belirlenmiştir.

Birincil Kod: Kalite:

İkincil ve Üçüncül Kod: Hammadde (ekoloji, kültürel işlemler, çeşit); Hasat (zaman, şekil), İşleme Teknolojisi (soğuk sıkım, iki faz ve üç faz kontinü sistemler), Kimyasal ve Duyusal Analiz (peroksit, serbest yağ asidi, meyvemsilik (koku), acılık ve yakıcı tad) 
Birincil Kod: Markalaşma

îkincil ve Üçüncül Kod: Tescil (güven, imaj, fiyat )

Birincil Kod: Yarışmalar

ikincil ve Üçüncül Kod: Farkındalık (tanınırlık, kanıtlamak)

Çizelge 2'de görüldüğü gibi birincil, ikincil kodlar ve üçüncül kodlarla ilgili görüşler nitel metod gereği görüşme yapılan firmaların birebir kendi konuşmalarından yapılan alıntılarla özetlenecek olur ise;

"Zeytinin her türlü aşamasını takip ediyorum, zeytin toplanmasından filitrasyon sürecine paketlemeye kadar. Bahçeden işlemeye, paketlemeye bütün süreci takip ediyorum. İstediğiniz kadar iyi hammaddeniz yani zeytininiz olsun bunu işletmede bitirirsiniz" (F1/I).

"Kaliteyi elde etmek için zeytin ağacını iyi besleyeceksin. Vermeden almamak gibi bir şeydir. Zeytin tarımında yeterli gübrelemeyi, doğru sürüm doğru budama bakım, bakamadığımız müddetçe gün geçtikçe kötüye gider bütün civarda bu ziraat bakımı performansını da kalite standartlımızı da koruyoruz. Zeytini doğru zamanda ve zedelenmeden topluyor ve bekletmeden naklediyoruz, seçiyoruz. Üretim sürecimizi su ile teması en aza indirgeyerek aşırı mekanik güç kullanımından kaçınıyoruz"(F2/I).

"Kalite hammaddeden başlar üretim aşamalarına da dikkat ederseniz kaliteli ürün elde edersiniz. Zeytinyağında da kalite odaklı çalışmaktayız. Bahçeden son tüketiciye giden her aşamaya kadar kalite bizim için son derece önemli birde gıda mühendisi olunca aşııı hassasiyet olmakta ( F5/I).

"Zeytinyağında kalite çok geniş bir konudur. Kaliteli üretim yapmak için hammaddeden, ağaca, ağaçtan fidana, fidandan budamaya toprak yapısına kadar uzanan önemli bir konudur"(F2-1/N).

"Kaliteli bir zeytinyağı üretiminde seçilecek zeytin cinsinden başlamak üzere, toprak bakımı, iklimin, sulamanın, organik üretimin, toplama şartının, erken hasadın, hasat sonrası bekletmeden sıkımın, soğuk sıkımın, sıkım şartlarının ayrı ayrı payları vardır" (F7-I/N).

Çünkü yağ asidi oluşumu, zeytinin çeşidine ve çevresel faktörlere iklim, yükseklik göre değişiklik göstermekte ve (ilyasoğlu, 2009) zeytinyağı elde etme sistemlerinde kullanılan su nedeni ile yağın fenolik bileşiklerinde azalma söz konusu olabilmektedir. Ayrıca zeytinyağının acılık şiddeti de yağ elde etme sistemlerine bağlı olarak değişmektedir (Köseoğlu, 2006).

"Kaliteli bir zeytinyağı olduğunu göstermekti. Insanların bunun düzgün hasat düzgün sıkım yaptığınızda yüksek kalitede zeytinyağı elde edildiğini göstermektir. Tanınırlık ve markamız gazetelerde yayınlar çıktı. İnsanların sosyal medya da konuşması."(F3/I)

"Zeytinin hasat zamanı zeytinyağı randımanını etkileyen en önemli unsurlardan biridir." (F6/N).

Zira hasat zamanı meyvedeki yağ oranını çok fazla etkilemektedir. Erken ya da olgunlaşmamış olarak hasat edilen zeytinlerden elde edilen yağ miktarları düşmekte iken duyusal açıdan ise çok büyük artışlar vardır. Yani aroma, tat, acılık gibi artışlar. Zeytinlerin hasat edildiği dönem geciktikçe meyveden alınan yağ oranı artmakta fakat göreli olarak klorofil içeriği fenolik miktarı ve bazı aromatik bileşiklerin miktarı azalmaktadır. Farkı dönemlerde hasat edilen zeytinlerden elde edilen yağların oranları da aromaları da farklılık göstermektedir (Yavuz ve Tekin, 2008).

"Sıfır hatada pozitif değerde yağı yakalayacaksınız dünyayla yarışacaksınız. Yağda acılık yakıcılık taze badem kokusu taze sebze kokusunu alacaksın. 90 gram mansiyon ödülüm var."(F1-/I).

"Zeytinyağı sektörü diğer sektörler gibi rekabet ortamındadır. Bu ortamda dikkat edilmesi gereken en önemli unsur marka kavramı olarak belirtilebilir. Ürünleri farklılaştırarak piyasada var olma yollarından biri olarak görülen marka, ülkemiz zeytinyağı sektörü açısından tam olarak kullanılamamaktadır."(F1/2).

"Markalaşmayla tanınma ile birlikte ürettiğiniz zeytinyağına bir karakter kazanma yanında uluslararası alanda yer edinmemizi sağladı. Markalaşmadığınızda başkasına fason üretim yapmış gibi oluyorsunuz, markalaştığınızda özel olduğunuzu görüyorsunuz. İyi fiyat iyi katma değer kazandırıyor."(F3/I)

"Yarışma bizim için tescillenmektir" (F2-I/N).

"Yurt içi ve yurt dışı pazarlama esnasında ödüller bizim için ispat oluyor" (F4-I/N).

"Uluslararası düzeyde neredeyiz bunu görmek istiyoruz." $\mathrm{F} 1-\mathrm{I} / \mathrm{N}$.

\section{SONUÇ}

Son yıllarda dünyada ve Türkiye'de, sağlıklı ve uzun yaşamak isteyen tüketicilerin talepleri nedeniyle zeytin ve zeytinyağı tüketimine üretim ve çok daha fazla önem ve dolayısıyla özen gösterilmeye başlanılmıştır.

Bu araştırmada, uzun yıllardır zeytinyağı üretiminde özel ve özenli üretim yapan uluslararası, ulusal ve her iki alanda da zeytinyağı kalite yarışmalarına katılan küçük kapasitede ancak kaliteli ve markalı üretim yapan ve kaliteli natürel sızma zeytinyağı üretmeyi yalnızca yarışmalar için değil kendilerine özel olarak amaç edinmiş ve kendilerini butik üretici olarak tanımlayan toplamda 21 adet firma yönetici/firma sahipleri ile birebir görüşülmüştür. Bu görüşmelerde katılımcılara yöneltilen sorularla onların demografik özellikleri, deneyimleri, markalaşma stratejileri sürecini başarı ile tamamlamak için (katma değer yaratan kaliteli üretim için dikkat ettikleri önemli noktalar ve bu bağlamda ürün farkıılaştırma, markalarının tanınırlığı vb.), uluslararası ve ulusal yarışmalara katılım durumları incelenmiştir.

Zeytinyağında kaliteli üretim, zeytin ağacının ve meyvesinin bulunduğu ekolojik ve agronomik koşullara, çeşide, hasada, danenin bahçeden taşınmasından yağa işlenmesine, işleme sırasındaki ve sonrasındaki şartlara, zeytinyağııın depolanması ve ambalajlanmasına dahil her aşamada önemlidir. Zeytinyağında kalite, kimyasal ve duyusal analizlerle tespit edilmektedir. Kimyasal analizde, serbest yağ asitliği, peroksit sayısı, ultraviyole ışı̆ı̆ında özgül soğurma ve polifenoller, duyusal analizde ise meyvemsilik, acılık ve yakıcılık en önemli kriterlerdir. Bu analizlerde dünyada ve Türkiye'deki standartlarda Avrupa Birliği, 
International Olive Council, FAO (Food Agricultural Organization-Codex Alimanterius), Türk Gıda Kodeksi, Türk Standartlar Enstitüsü (TSE) ve TÜRKAK esas alınmaktadır.

Zeytinyağında markalaşma ise diğer gıda ürünlerinden farklı olmayan bir biçimde kalite ile markayı buluşturmayı kapsayan ve teorik olarak üretim stratejileri ile ifade edilen bir süreci ifade etmektedir. Diğer yandan net olarak bilinen kaliteli ve markalı zeytinyağı üreten firmaların kalite-marka süreçlerinde, bu emeklerini ulusal ve uluslararası yarışmalardan kazanılan ödüllerle tescil ettirme talepleri ve başarılarının tescili onlara yol göstermektedir.

Kendilerini butik üretici olarak tanımlayan firmaların bir amacı da "Türk zeytinyağı" imajını oluşturarak dünyada zeytinyağı üretiminde lider konumda olan ülkeler arasında yer almaktır. Böylece bu firmalar kalite ve markalarını, hem ulusal hem uluslararası platformda farklılıkları ve tanınırlıklarını önceleyerek ispatlamaktadırlar. Bu firmalar, verimden çok kaliteye önem verdikleri için işletme maliyetindeki sorunların üstesinden ise ancak birlik ve beraberlik içerisinde hareket ederek gelebileceklerini belirtmektedirler. Nitekim sektördeki buna yönelik ilk adım bir çatı kuruluşu altında toplanılarak atılmıştır.

\section{KAYNAKLAR}

Baş M, Yaman EN (2015) Butik Zeytinyağı Üretimi Yapan İşletmelerde Stratejik Marka Yönetimi. Üçüncü Sektör Sosyal Ekonomi, 50 (2): 102-121.

Demir P (2015) Marka ve Marka Bilinirliği Yaratmak Advergaming ve Marka İlişkisi. Bahçeşehir Üniversitesi Sosyal Bilimler Enstitüsü, Yüksek Lisans Tezi, İstanbul.

Dölekoğlu ÖC (2003) Tüketicilerin İşlenmiş Gıda Ürünlerinde Kalite Tercihleri, Sağlık Riskine Karşı Tutumları ve Besin Bileşimi Konusunda Bilgi Düzeyleri (Adana Örneği). Tarımsal Ekonomi Araştırma Enstitüsü. Proje Raporu, Yayın No: TEAE:105, ISBN 975-407-128-4: 115. Ankara.

Erdil ST, Uzun Y (2010) Marka Olmak. Beta Yayınları. 2.Baskı. s, 448, Ankara.

Güney N (2015) Bilgi Yönetiminde, Kalite Yönetim Sistemlerinin Rolü ve Bir Uygulama. Beykent Üniversitesi Sosyal Bilimler Enstitüsü, İşletme Anabilim Dalı, Yüksek Lisans Tezi, İstanbul.

ilyasoğlu H (2009) Ayvalık ve Memecik Zeytinyağlarının Coğrafi İşaretleme Amacıyla Karakterizasyonu. İstanbul Teknik Üniversitesi Fen Bilimleri Enstitüsü, Doktora Tezi, İstanbul.
ÖZDOĞAN D, TUNALIOĞLU R

İpek HZ (2010) Markalaşmanın İşletmelerin Rekabet Gücü Üzerindeki Etkisi ve Türk Zeytinyağı Sektöründe Bir Inceleme. Balıkesir Üniversitesi Sosyal Bilimler Enstitüsü, Yüksek Lisans Tezi, Balıkesir.

Kalaycı Ş (2016) SPSS Uygulamalı Çok Değişkenli İstatistik Teknikleri. Asil Yayın, 7. Baskı, s: 419, Ankara.

Kalof L, Dan E, Dietz T (2008) Essentials of Social Research. Typeset by BookEns. Bell and Bain Ltd, GlasgowM. First published. s, 235, New York.

Keçeli T (2008) Zeytinyağının Depolanması ve Ambalajlanmasının Yağ Kalitesine Etkileri. Türkiye 10. Gıda Kongresi, 21-23 Mayıs, 625-628, Erzurum.

Kızılaslan H, Yalçın A (2012) Tüketicilerin Gıda Güvenliği İle İlgili Tutum ve Davranışları Samsun Ili Örneği. Tarımsal Ekonomi ve Politika Geliştirme Enstitüsü. Yayın No: TEPGE: 213, ISBN 978-605-4672-39-4: s:79. Ankara.

Köseoğlu O (2006) Zeytinden Yağ Elde Etme Sistemlerinin Zeytinyağının Kalitesi İle Acılığı Üzerine Etkileri. Ege Üniversitesi Fen Bilimleri Enstitüsü, Yüksek Lisans Tezi, İzmir.

Özata E, Cömert M (2016) Zeytinyağı ve Sağlıklı Yaşam. Zeytin Bilimi 6 (2): 105-110.

Özdoğan D, Tunalıŏlu R (2017) Zeytinyağında Kalite. Zeytin Bilimi 7 (1): 25-31.

Parmak F (2011) Kalite Odaklı Markalaşma Sürecinde Kalite Maliyetleri. Marmara Üniversitesi Sosyal Bilimler Enstitüsü, Yüksek Lisans Tezi, İstanbul.

Peri C (2014) The Extra-Virgin Olive Oil Chain. The ExtraVirgin Olive Oil Handbook, First Edition. (Edited by Claudio Peri). Published by Wiley Blackwell, Chapter $1 / 1, \mathrm{~s}, 5-10$, Italy.

Schutt RK (2011) Investigating The Social World The Process And Practice Of Research, Chapter 10: Qualitative Data Analysis. SAGE Publications, 640: 321.

Tunalıoğlu R (2010) Türkiye'de Zeytinyağı Pazarlamasında Gıda Güvenliği ve Kalite Güvence Sistemlerinin Uygulanması ve Gelişmelerin Değerlendirilmesi. Tarım Ekonomisi Dergisi. s. 59-66, Aydın.

Yavuz H, Tekin A (2008) Çeşit, Bölge ve Hasat Zamanının Zeytinyağı Kalitesine Etkisi. I. Ulusal Zeytin Öğrenci Kongresi, 17-18 Mayıs, 42-45, Edremit-Balıkesir

Yıldırım R, Tunalıoğlu R (2016) Aydın'da karasu sorunu ve zeytinyağı işletmelerinin çözüme yönelik tercihlerinin incelenmesi. Adnan Menderes Üniversitesi Ziraat Fakültesi Dergisi, 13(2) : 1 - 1 
